UDC 621.317

DOI https://doi.org/10.18524/1815-7459.2020.3.212951

\title{
IMPLEMENTATION AND EXPERIMENTAL RESEARCH OF THE TEST AND REFERENCE SIGNALS DIGITAL GENERATORS FOR IMPEDANCE MEASUREMENT IN WIDE FREQUENCY BAND
}

\author{
V. G. Melnyk', P. I. Borschov', V. K. Beliaev², O. D. Vasylenko', O. L. Lameko ${ }^{1}$, O. V. Slitskiy ${ }^{1}$ \\ ${ }^{1}$ Institute of electrodynamic National Academy of Sciences of Ukraine, 56 Pr. Peremohy, 03057, \\ Kyiv-57. E-mail: melnik@ied.org.ua \\ ${ }^{2}$ National University of Life and Environmental Sciences of Ukraine, Heroyiv Oborony st., 15, \\ Kyiv, 03041, Ukraine
}

\section{IMPLEMENTATION AND EXPERIMENTAL RESEARCH OF THE TEST AND REFERENCE SIGNALS DIGITAL GENERATORS FOR IMPEDANCE MEASUREMENT IN WIDE FREQUENCY BAND}

\author{
V. G. Melnyk, P. I. Borschov, V. K. Beliaev, O. D. Vasylenko, O. L. Lameko, O. V. Slitskiy
}

\begin{abstract}
The structure and construction of the unified basic measuring module for creation of the broadband means for impedance measurement are described, which was used by us to study the important metrological characteristics of the test and reference signals digital generators for such devices. The sources and the magnitudes of the modular and phase errors are determined for the measuring channels with direct conversion of the impedance parameters and with compensation of the phase shift of the signal in the measurement object, as well as for the channels with balancing the measuring circuit modulo and phase. The researches shown attainability of measurement errors of an object impedance on absolute value and on its phase angle tangent less than $0.1 \%$ at frequencies up to $1 \mathrm{MHz}$. At the frequency of $1 \mathrm{kHz}$, the measurement error on the quadrature parameter did not exceed $0.001 \%$. The study of the two-phase generators with precise adjustment of phase difference of reference and test signals showed the ability to achieve the time errors of their formation no more than a few nanoseconds.
\end{abstract}

Keywords: impedance, measurement, phase error, test signal, reference signal.

\section{РЕАЛІЗАЦІЯ ТА ЕКСПЕРИМЕНТАЛЬНІ ДОСЛІДЖЕННЯ ШИРОКОСМУГОВИХ ЦИФРОВИХ ГЕНЕРАТОРІВ ТЕСТОВИХ І ОПОРНИХ СИГНАЛІВ ДЛЯ ВИМІРЮВАННЯ ІМПЕДАНСУ}

\section{В. Г. Мельник, П. І. Борщуов, В. К. Бєляєв, О. Д. Василенко, О. Л. Ламеко, О. В. Сліи̧ький}

Анотація. Описано структуру та конструкцію уніфікованого базового вимірювального модуля, призначеного для побудови широкосмугових засобів визначення параметрів імпедансу, який було використано для досліджень важливих метрологічних характеристик цифрових генераторів тестових та опорних сигналів, що застосовуються в таких приладах. Визначено дже-

(c) В. Г. Мельник, П. І. Борщов, В. К. Бєляєв, О. Д. Василенко, О. Л. Ламеко, О. В. Сліцький, 2020 
рела і оцінено величини модульних і фазових похибок вимірювальних каналів 3 прямим перетворенням параметрів імпедансу та компенсацією фазового зсуву сигналу в об’єкті вимірювання та каналів зі зрівноваженням вимірювального кола за модулем і фазою. Показано, що похибки за модулем та тангенсом фазового кута об’єкта вимірювання не гірше $0,1 \%$ на частотах до 1 МГц. На частоті 1 кГц похибка по квадратурному параметру не перевищувала 0,001\%. Дослідження двофазних генераторів з точним регулюванням різниці фаз когерентних тестових та референсних сигналів показали можливість досягти часових похибок при їх формуванні не більше кількох наносекунд.

Ключові слова: імпеданс, вимірювання, фазова похибка, тестовий сигнал, опорний сигнал.

\title{
РЕАЛИЗАЦИЯ И ЭКСПЕРИМЕНТАЛЬНОЕ ИССЛЕДОВАНИЕ ШИРОКОПОЛОСНЫХ ЦИФРОВЫХ ГЕНЕРАТОРОВ ТЕСТОВЫХ И ОПОРНЫХ СИГНАЛОВ ДЛЯ ИЗМЕРЕНИЯ ИМПЕДАНСА
}

\author{
В. Г. Мельник, П. И. Борщеев, В. К. Беляев, А. Д. Василенко, А. Л. Ламеко, А. В. Слицкий
}

Аннотация. Описаны структура и конструкция унифицированного базового измерительного модуля, предназначенного для построения широкополосных средств определения параметров импеданса, который был использован для исследований важных метрологических характеристик цифровых генераторов тестовых и опорных сигналов, применяемые в таких приборах. Определены источники и оценены величины модульных и фазовых погрешностей измерительных каналов с прямым преобразованием параметров импеданса и компенсацией фазового сдвига сигнала в объекте измерения, а также каналов с уравновешиванием мостовой цепи по модулю и фазе. Достигнуты погрешности по модулю импеданса объекта измерения и тангенсу его фазового угла не хуже $0,1 \%$ на частотах до 1 МГц. На частоте 1 кГц погрешность по квадратурному параметру не превышала $0,001 \%$. Погрешности по времени формирования тестовых и референсных сигналов в двухфазных генераторах с точной регулировкой разности их фаз не превышали нескольких наносекунд.

Ключевые слова: импеданс, измерения, фазовая погрешность, тестовый сигнал, опорный сигнал.

\section{Introduction}

The article [1], published in a previous issue of the journal, shows an effective way to solve the main problem in creation of the broadband means for impedance measurement - significant increasing of errors under dividing the information signal into quadrature components with increasing frequency. The results of the development of broadband digital generators of test and reference signals using Johnson ring meters, which ensure very small phase errors, are presented. The structures and principles of operation of impedance meters that can be implemented on their basis with using the impedance - voltage conversion, the bridge method with balancing by module and phase of the imbalance signal, as well as their combinations are considered. The following are the results of development and metrological research of fundamentally important characteristics of the prototype of the basic module of a high-precision, broadband measuring channel designed for the construction of information and measuring systems.

\section{Research equipment}

Based on a set of new technical solutions for the test and reference signal generators described in [1] as well as software and hardware for par- 
allel-serial conversion of information signals [2], a new basic measuring module MXP-6 was developed. This module can be the basis for the creation of the impedance-meashuring devices that are competitive with respect the best world models of similar equipment. More detailed information on these issues can be found in the references of the article [1], in [3], in the review [4], in the materials of joint works of the national scientific school on precision impedancemetry and NIST (USA) $[5,6]$, as well as on sites of leading foreign companies, in particular [7 - 9].

Figure 1 shows its structure and photograph as part of the measurement and information system.

The module includes generator of test and reference signals of GTRS, the unit of conversion of informative signals based on three multi-bit integrating ("multi-slope") ADC of the MAX-132 type with the synchronous (phase-sensitive) detector (SD) on the input, a source of constant reference voltage Uref for ADC and GTRS. The block diagram also includes precision and high-discrete voltage regulator with direct and inverse output based on two integrated 12-bit analog-to-digital converters DAC1 and DAC2, type AD7945 and operational amplifiers: current-to-voltage converter (I/U) and inverter (INV), as well as microcontroller (MC), type STM32L152. The specialization of the measuring channel for specific tasks performes the measuring block (MB), to which the object under study is connected (sensor, electrochemical cell, electrical product). The blocks of the generator, controller with display and keyboard and measuring block realised as replaceable submodules, which installed in the connectors of the motherboard. Motherboard also houses the other components of the circuit in Fig. 1, power supply and various auxiliary components. A feature of the presented scheme is the high-discrete regulation of the GTRS output voltage (with a discreteness of one unit of ADC scale) by changing the reference voltage of the generator's DAC with using the paired DAC1 and DAC2 of the base module. This allows you to explore the characteristics of the generator and the conversion unit by automatic step-by-step scanning.

The DAC includes 74CH4053 chips (3 switches for 2 positions), which connect 8 precision resistors first to the source of the reference voltage of positive polarity, and then to the inverted reference voltage. The DAC of the generator uses an operational amplifier AD8032 with a frequency band of $80 \mathrm{MHz}$, which produces the output quasi-sinusoidal signal $\mathrm{U}_{\mathrm{T}}$. In the decoder of the generator introduced the logic scheme "AND" of coincidence of the logical state of the triggers in the last cycle of the counter cycle and of the clock pulse. It forcibly sets this state (phase $0^{\circ}$ ) to prevent the malfunction of the ring counter due to failures of the triggers under the action of interference. This node is implemented on a threeinput circuit matching high levels of logic signals (74HC10). Its output is connected to the inputs of the triggers to set them to state " 0 ". When imple-

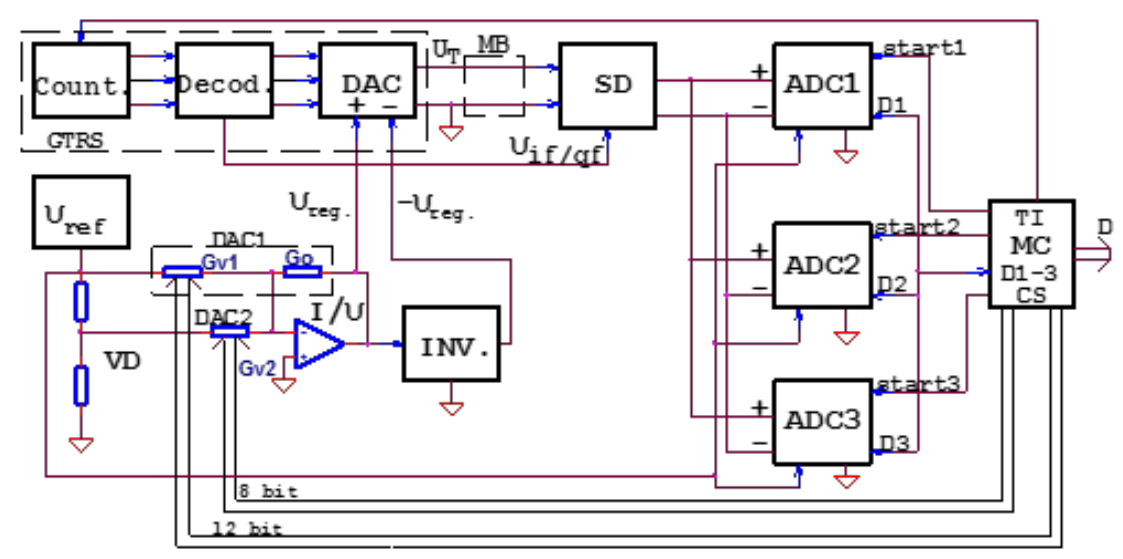

$\mathbf{a}$

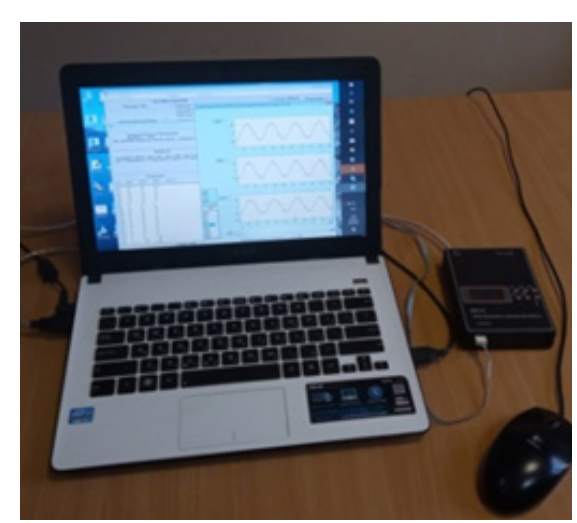

b

Figure 1. The photo of the information-measuring system for experimental research and the structure of its measuring module 
menting a two-phase test signal generator [1], in the master shaper is added another element of the chip $74 \mathrm{HC} 10$, which generates for slave shaper sync pulses "sync. 90" ("mid of cycle"), which corresponds to the phase angle $90^{\circ}$ of the its output signal.

The different variants of constructive decisions of the generator block were researched. The best frequency and phase characteristics are achieved by using chips with minimal dimensions (distance between the central pins of $0.635 \mathrm{~mm}$ ) to reduce the size of the unit. To optimize the connections, the mounting of components were performed on both sides of the printed circuit board. The multilayer board was not used due to ambiguous expectations regarding the impact of such a decision on the characteristics of the generator. This issue requires further research. The photos of prototype samples of the generator unit and the entire electronic unit of the base module MXP-6 are shown in Fig. 2. The variant with a paired, two-phase generator has a block of two single-phase generators and the scheme of their synchronization, which are installed one above the other (Fig. 2c), or next to each other (Fig. 2b).

We aimed the experimental studies of the test and reference signal digital generators at assessing the compliance of the parameters of the syn- thesized signals with the theoretically expected, based on the technical characteristics of the element base used and the proposed principles of reducing time shifts and phase errors. The operation of the circuit and the main parameters of the generated signals with frequencies up to $1 \mathrm{MHz}$ were investigated using a basic module with a single-phase digital generator. The basic module with a two-phase generator was used to study the time and phase differences of the synthesized signals of the master and slave generators.

The clocking of the generators counters performed by the controller of the base module based on the STM32L152 microcontroller in the range from $32 \mathrm{~Hz}$ to $32 \mathrm{MHz}$, which corresponds to the frequencies of the output signals $1 \mathrm{~Hz}-1 \mathrm{MHz}$. To control the two-phase generator, a unit for adjusting the delay of the clock sequence and synchronization of the slave generator relative to the master was additionally installed.

A two-channel digital oscilloscope from Tektronix TDS2012 with a sampling frequency of 1 $\mathrm{GHz}$ and a bandwidth of $100 \mathrm{MHz}$ was used in the study of generator signals. Measurement of their amplitude and phase characteristics was performed using the measuring channel blocks (SD, $\mathrm{ADC}, \mathrm{DAC} 1)$. The following is a brief description of the studies performed and their results.

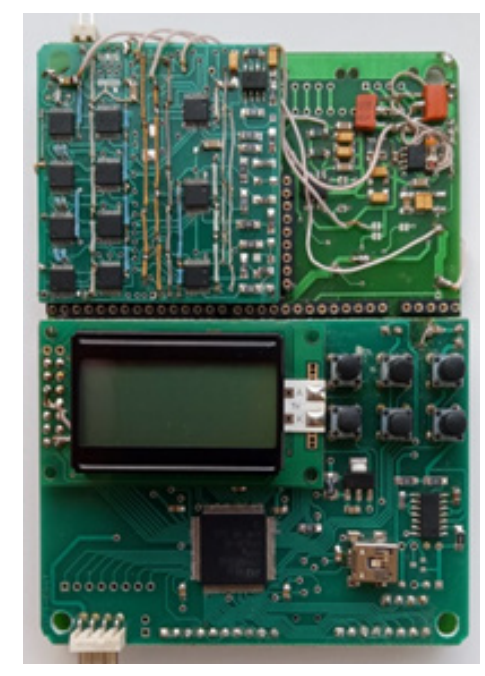

a

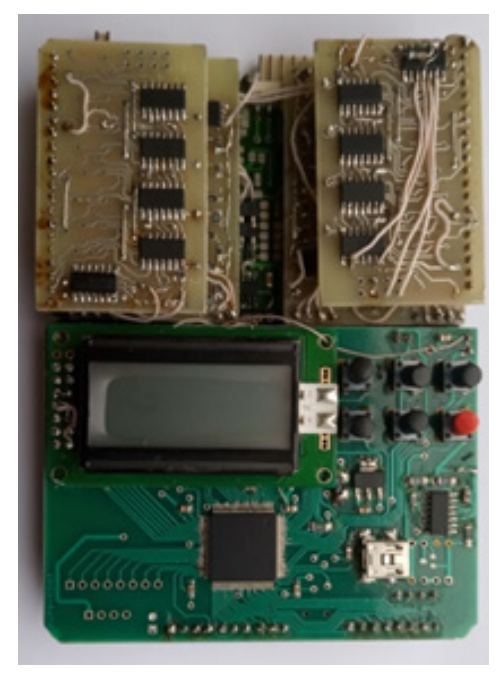

b

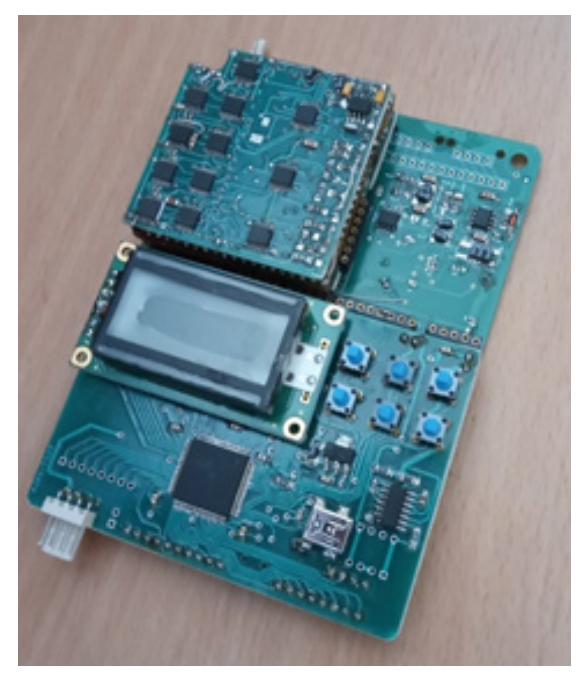

c

Figure 2. The photos of an experimental samples of the generator unit and the entire electronic unit of the base module MXP-6 


\section{The purpose and content of metrological research of the measuring channel}

The general scope of the unified basic module covers several areas that have particular requirements for its main characteristics: the number of measurement channels; frequency range of test signals; accuracy and resolution; range of measured values and sensitivity; ratio of the impedance parameters of the object; restrictions on the level of test signals and measurement speed. The possibilities for improving each of these characteristics depend on the limitations of the others. Testing the metrological characteristics of the basic measuring channel in the entire multidimensional space of these requirements is technically impossible and practically impractical. Therefore, the studies were focused on determining the main results in the directions of the last stage of the work: on assessing the accuracy of regulation of the test signal and its phase relationships with the reference signals $U_{\text {if }}$ ("in-fase") та $U_{\text {qf }}$ (quadrature), as well as on the study of possible sources of phase errors in measuring impedance parameters - of the phase delays under formation of a quasi-sinusoidal voltage .

\section{The research of the of regulation character- istics of the test signal generator}

The amplitude of the output signal of the digital generator in the researched channel can vary from 0 to the reference voltage of the $\mathrm{ADC}(0.5$ $\mathrm{V})$ using the DAC1, which is part of the base module MXP-6. During the research, the control code of DAC 1 changed from 0 to 2048 by alternate installation in "1" of one of the digits: from the 1st (LSB) to the 12th (MSB). Values of 3072 (two high bits in "1") and 4095 (all bits in "1") were also set. The alternating voltage at the generator output were measured by the ADC unit of the module with a synchronous detector by separation on two components: common-mode ("in-phase") and quadrature with a test voltage. At the maximum code of DAC1 (4095), the in-phase component of the test signal was about 262,000 units of ADC discreteness. According to the estimation of the accuracy of the information signals conversion block, its total reduced error (integral and differential nonlinearity, random component) did not exceed several thousandths of a percent.
The obtained values of the in-phase component were compared with the linear characteristic passing through " 0 " and the value of the ADC reading with the DAC code 2048 . The error in the quadrature component was defined as the difference between ADC reading in the current state and with the code "0" DAC1. When evaluating the obtained control characteristic, an accurate millivoltmeter was also used and the differential nonlinearity of DC reference voltage regulation by means of DAC1 was taken into account (AD7945 chip has error of about $0.01 \%$ ). The studies were performed at two frequencies: $1 \mathrm{kHz}$ and $1 \mathrm{MHz}$ with two instances of generators: with chips in TSSOP-16 housings (copy 1, Fig. 2a) and larger one, SO-16 (copy 2, Fig 2b). The obtained results are presented in graphical form. Fig. 3 shows the relative error of regulation of the main phase component (amplitude) of the test signal, Figs. 4 - the value of the reduced relative error of its quadrature component (error of the tangent of the phase angle): a - frequency $1 \mathrm{kHz}$ (copies 1 and 2), b frequency $1 \mathrm{MHz}$ (copy 1). The level of quadrature (phase) error of copy 1 is much lower due to the optimization and miniaturization of the structure.

The obtained values of the errors in the regulation of the reference voltage of the DAC of the digital generator and the characteristics of the regulation of the test voltage at frequencies of $1 \mathrm{kHz}$ and $1 \mathrm{MHz}$ in the range of codes $0-2048$ (half of the dynamic range) do not exceed the values determined by the metrological characteristics on the direct current of the AD7945 chip (DAC1). In the upper half of the dynamic range, the non-linearity of regulation increases to $0.3 \%$. It was found that the reason for this is the dependence of the resistance of the keys used in the DAC of the generator (high-speed and low-cost chips 74HC4053) from the currents switching in this part of the dynamic range (up to $1.7 \mathrm{~mA}$ ). Reducing this nonlinearity to an insignificant level is possible by means of algorithmic correction (it is quite stable), or by using keys with lower resistances in the open state (if available at an affordable price and speed). It is also possible by reducing the voltage regulation of the DAC (Ureg) or by increasing the resistances connected in series with the keys to form the stairs of a quasi-sinusoidal voltage. The latter, however, impairs the phase characteristics of the genera- 


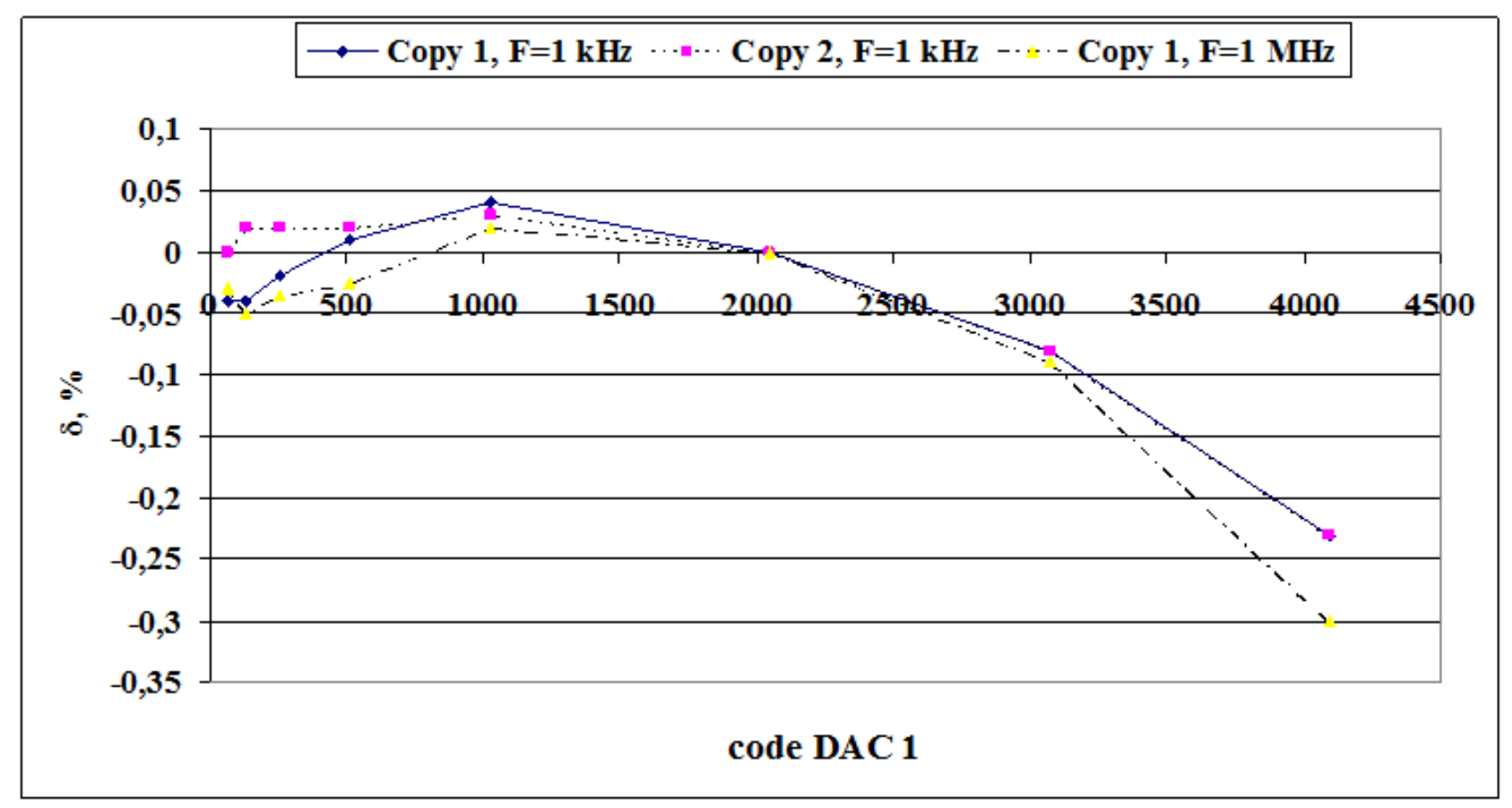

Figure 3. The relative error of regulation of the main phase component (amplitude) of the test signal

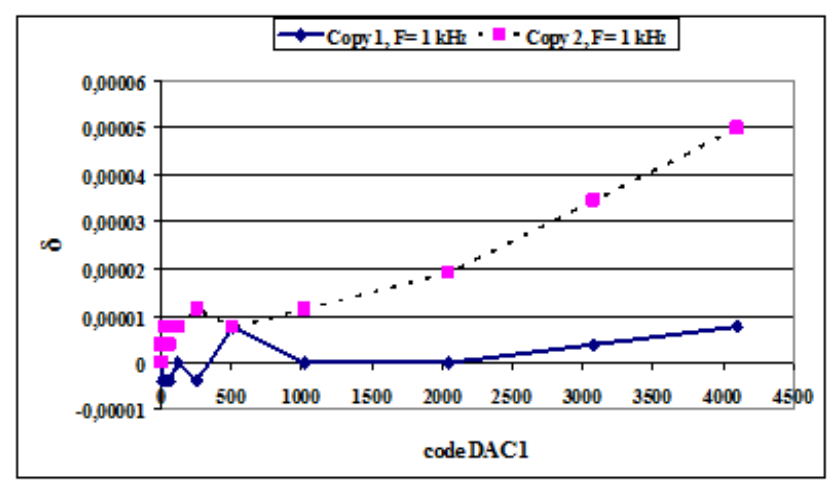

$\mathbf{a}$

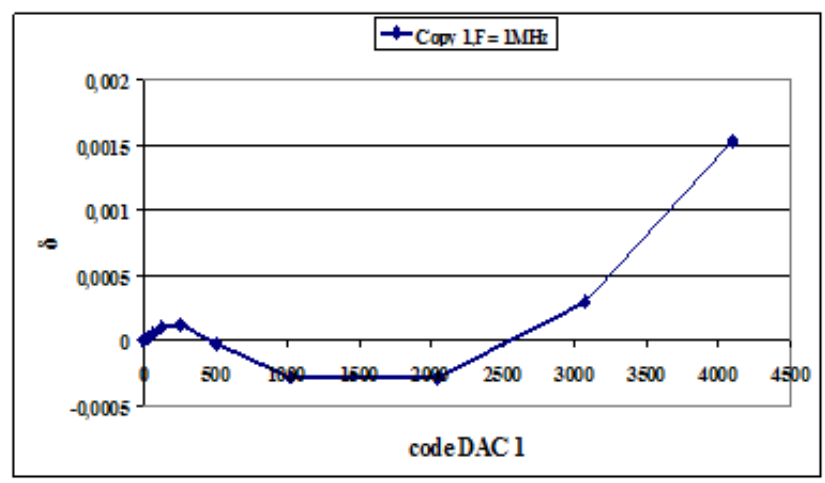

b

Figure 4. The value of the reduced relative error of quadrature component of the test signal (error of the tangent of the phase angle): a - frequency $1 \mathrm{kHz}$ (copies 1 and 2), b - frequency $1 \mathrm{MHz}$ (copy 1)

tor in the upper part of the frequency range. At the same time, we note that the indicated error is significant only for the precise measurements by bridge and combined methods, but they are carried out at lower frequencies.

The results obtained in this study show the possibility of the absence of a practically significant phase error of the regulation characteristic at a frequency of $1 \mathrm{kHz}$. The relative error in the quadrature component is about $10^{-3}$ at a frequency of $1 \mathrm{MHz}$. Note, the presented data are the endto-end characteristic of the conversion channel: from its input (the reference voltage $\mathrm{U}_{\text {ref }}$ source) to its output (ADC), and include the errors of all its blocks except, in this case, the errors of the measuring circuit block. In instruments for practical use, the overall error also depends on the measurement methods and the characteristics of the measuring circuit.

The study of phase delays under formation of the test and reference signals.

Fig. 5a shows the waveforms of the test quasi-sinusoidal signal and the common-mode, $\mathrm{U}_{\mathrm{if}}$ ) 
reference signal for a synchronous detector at a frequency of $1 \mathrm{MHz}$. Fig. 5 b, c shows a portion of the reference and test signal near zero value of the test signal at frequencies of $125 \mathrm{kHz}$ and $1 \mathrm{MHz}$. The time delay of a quasi-sinusoid relative to the front of the reference signal is about $30-40 \mathrm{nsec}$ (front duration is $10 \mathrm{nsec}$.). It is due to the delay in the operation of the keys of the DAC generator (about $20 \mathrm{nsec}$ ) and the delay in its operational amplifier. The delay in the keys is fully compensated by the synchronous detector delay relative to the front of the reference signal. The delay in the operational amplifier can be reduced by introducing a small inductance in the feedback. It was proved by experimental studies (Fig. 4 b) that the phase error of the through conversion channel not exceed several nanoseconds in the range from infra-low frequencies to $1 \mathrm{MHz}$.

The measuring channel with a two-phase digital generator which was developed on the basis of the stated early [1] principles, can operate in the mode of balancing the bridge circuit on modulo and phase of the output signal at operating frequencies up to $62.5 \mathrm{kHz}$. The limiting factors are the clock frequency of the microcontroller (32 $\mathrm{MHz}$ ) of this device and the minimum required discreteness of regulation of the phase delay of the signals of the slave generator, which should be no worse than $1 \%$ of the phase range $\pm 90^{\circ}$ for the bridge balancing. It is $0.7^{\circ}$ at this frequency. In this case, the accuracy of phase balancing of the bridge provides an insignificant effect of the quadrature component of the impedance on the measurement accuracy of its main parameter. An increase in the clock frequency above $32 \mathrm{MHz}$ is impractical, taking into account the purpose and area of this development. Therefore, a study of the functioning of a two-phase generator and phase relations between its signals was carried out at a frequency of $62.5 \mathrm{kHz}$.

The block of formation of clock pulses (clock sequencer, [1] fig. 3), realized in the tested sample of the two-phase generator, provides exact antiphase of the quasi-sinusoidal test signals $\left(\mathrm{U}_{\mathrm{T} 2}\right.$ lags behind $\mathrm{U}_{\mathrm{T} 1}$ on a phase on $180^{\circ}$ ) under 4-bits control codes "delay1", "delay 2" accordingly 7, 15. Under control codes $0,0 \mathrm{U}_{\mathrm{T} 2}$ lags behind $\mathrm{U}_{\mathrm{T} 1}$ on phase on $90.7^{\circ}$, and at codes $15,15 \mathrm{U}_{\mathrm{T} 2}$ is ahead of $\mathrm{U}_{\mathrm{T} 1}$ by $90^{\circ}$. The fig. 6 shows the oscillograms of the reference signal "in-phase"of the master generator and the output signals of the slave generator at the phase delay codes of the slave generator 15 ; 15 (a); 0; 0 (b); 7, 15 (c).

Such phase relations allow balancing the bridge circuit with the reference measure of active resistance at any character of the measured impedance. The materials of experimental studies of the test and reference signals phase relationships in the states that determine the potential phase characteristics of the measuring channel given below.

In fig. 7a shows the time ratios of the reference signals $\mathrm{U}_{\mathrm{if}}, \mathrm{U}_{\mathrm{qf}}$ ("in-phase" or quadrature with $\mathrm{U}_{\mathrm{T}}$ ) of the master (0) and slave (v) generators at zero values $(0 ; 0)$ of the phase delay codes of the slave generator (delay code 1, 2 in Fig. 3 [1]).

The fronts of the $\mathrm{U}_{\mathrm{IF}}$ and $\mathrm{U}_{\mathrm{QF}}$ reference volt-

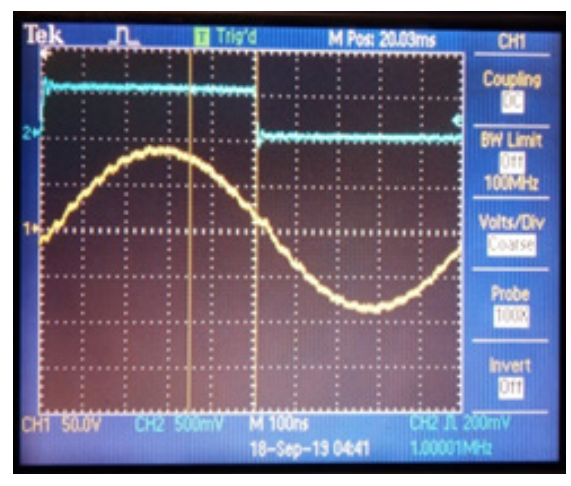

$\mathbf{a}$

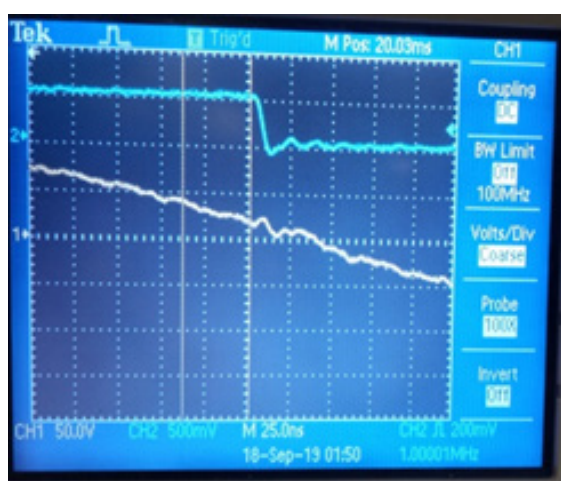

b

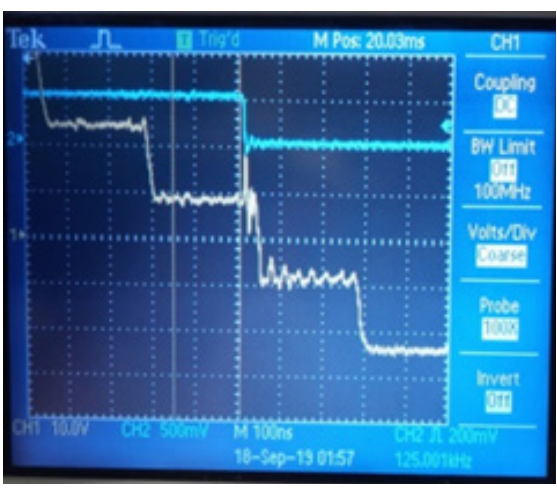

c

Figure 5. The complete period of the quasi-sinusoidal signal and reference signal with same phase at a frequency of $1 \mathrm{MHz}$ (a); the reference and the test signal (bottom) near its zero value at frequencies of $125 \mathrm{kHz}$ and $1 \mathrm{MHz}(\mathrm{b}, \mathrm{c})$ 
ages of the subordinate generator in this (initial) state of FD 2, 3 counters (Fig. 3 [1]) are shifted by one control step ( $30 \mathrm{nsec}$.) relatively to the $\mathrm{U}_{\text {if }}$ and $\mathrm{U}_{\mathrm{qf}}$ reference voltages of the master generator. The photo (Fig. $7 \mathrm{~b}$ ) shows the corresponding oscillograms obtained in experimental studies.

Fig. 8 a shows the "in-phase" reference signal of the master generator (above) and the quadrature reference signal of the slave generator (in the same phases) with the phase delay control codes 15, 15. Fig. 8 b shows the time shift of the reference signal of the slave generator relative to the master (above) by 30 nsec. when changing the control code on one unit of discreteness (from 7, 15 to 7,14$)$.

Fig. 9 shows the shift in time (about $30 \mathrm{~ns}$ ) of the quasi-sinusoidal voltage stairs of the master generator (a) and voltage stairs of the slave generator $(b, c)$ in the area of their zero values relatively reference voltage $U_{\text {if }}$ of the master generator. Fig $9 \mathrm{~b}$ corresponds the phase delay code 7,15 , as well as relatively quadrature reference voltage $\mathrm{U}_{\mathrm{qf}}$ of the master generator under the phase delay code of the slave generator 15,15 (c).

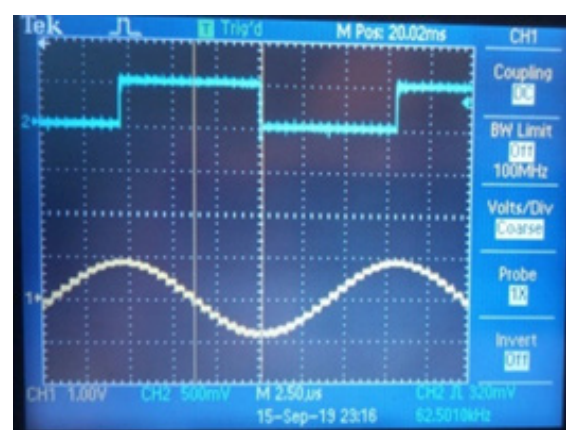

a

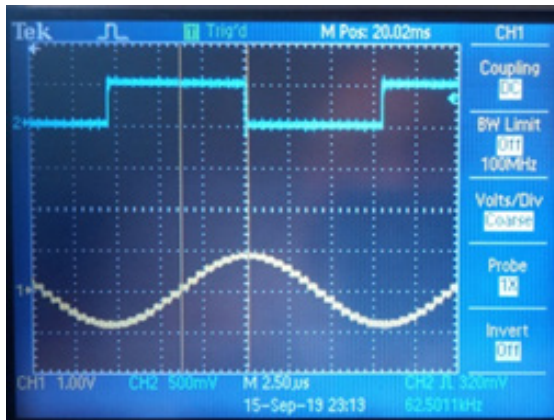

b

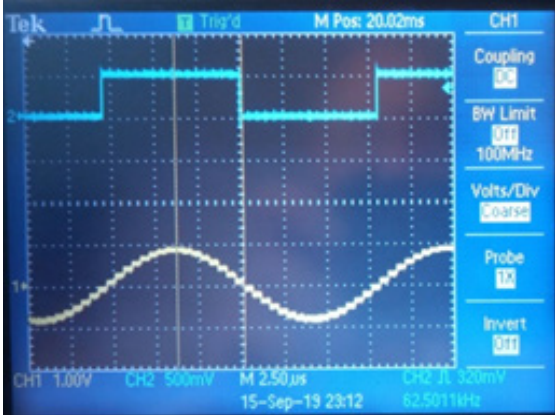

c

Figure 6. The reference signal of the master generator $U_{\text {if }}$ and the quasi-sinusoidal signals of the slave generator under different codes of phase delay

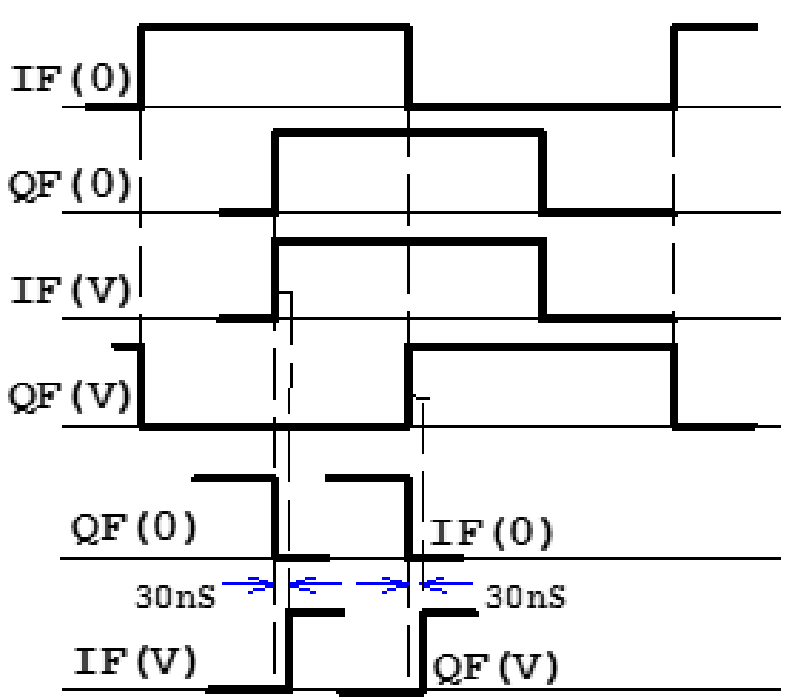

$\mathbf{a}$

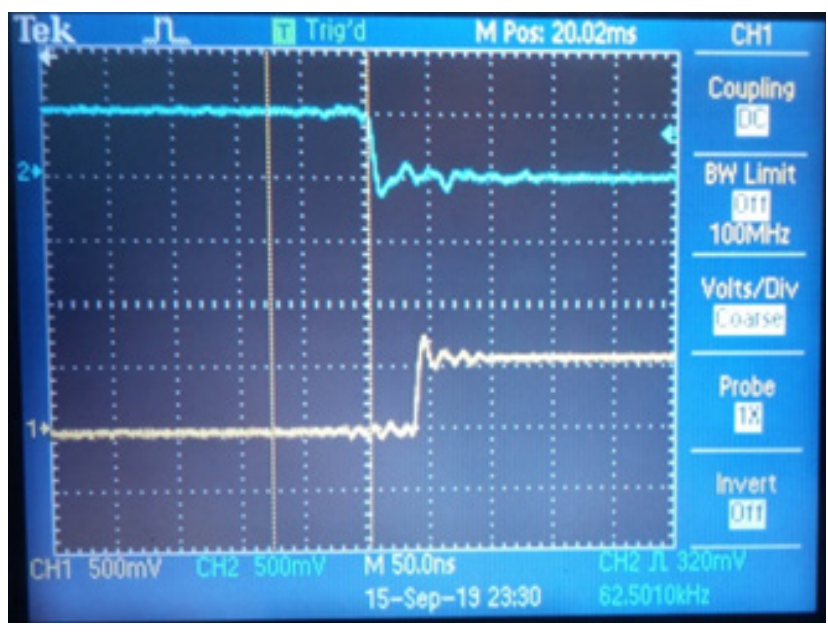

b

Figure 7. Time ratios between reference signals $\left(U_{\text {if }}\right.$ and $\left.U_{q f}\right)$ of the master $(0)$ and slave $(v)$ generators at different phase delay codes 


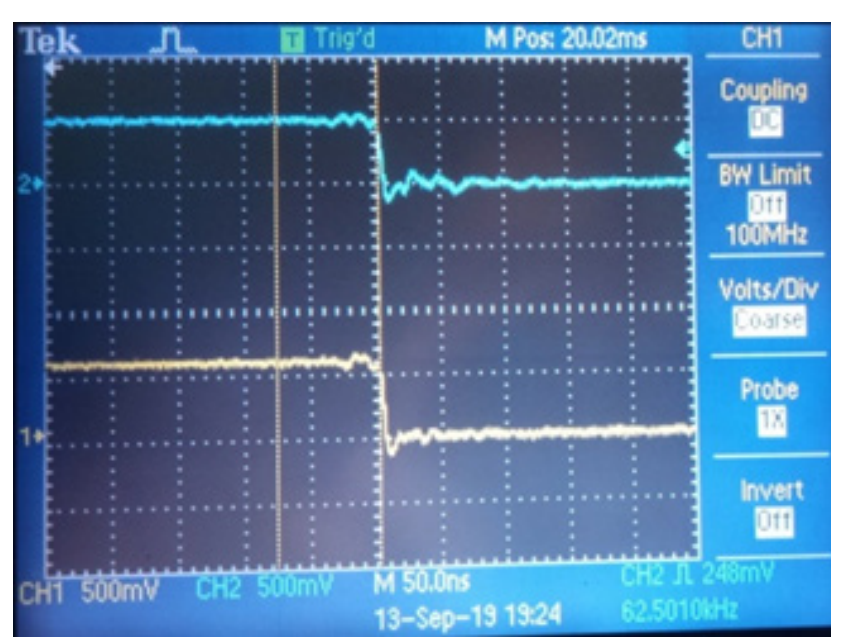

a

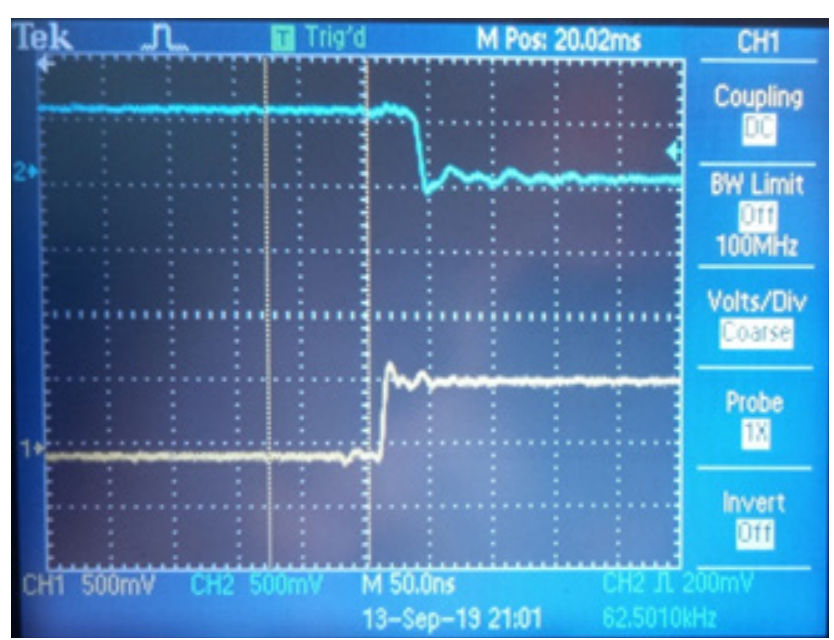

b

Figure 8. The reference signal $U_{\text {if }}$ of the master (above) and the quadrature reference signal $U_{q f}$ of the slave generator under phase delay codes 15, 15; time shift of the reference signal of the slave generator relative to the master (above) by 30 nsec. when changing the phase delay code from 7, 15 to 7, 14 (b)

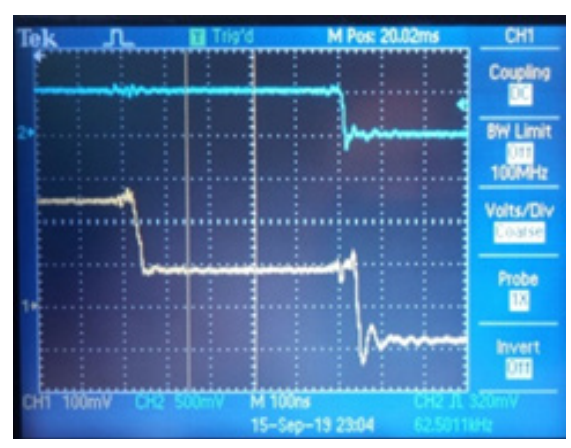

$\mathbf{a}$

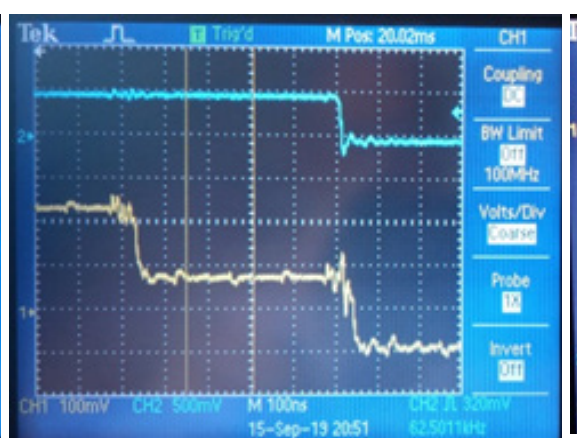

b

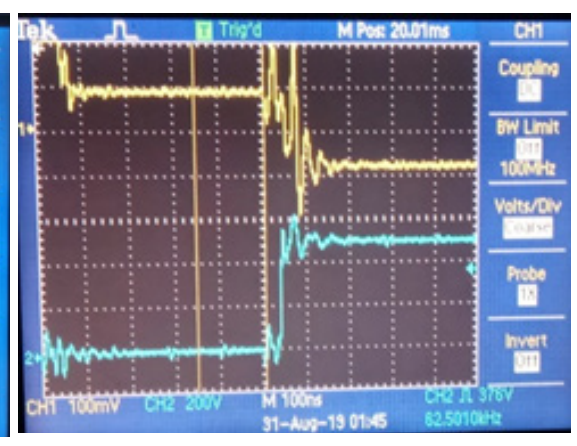

C

Figure 9. Time shift (about 30 nsec.) of the master generator's quasi-sinusoidal voltages stairs (a) and the slave generator's stairs $(b, c)$ relatively to $U_{\text {if }}$ of the master generator under phase delay codes 7,15 (b) or relative to $U_{q f}$ under codes 15, 15 (c)

Fig. $10 \mathrm{a}, \mathrm{b}$ shows the delay (15 - $20 \mathrm{nsec}$.) the fronts of the pulses of the formation of quasisinusoidal voltage at the outputs of the DAC keys (bottom) relatively to the pulse front at the key inputs near the values of the phase angle $90^{\circ}$ and $180^{\circ}$, respectively. The delay in the formation of the quasi-sinusoidal voltage stairs at the output of the DAC (30 nsec.) relatively to the pulse front at the input of the DAC key is shown in Fig. $10 \mathrm{c}$.

Fig. 11 shows the stairs of the output quasisinusoidal signals of the master (above) and slave generators (in opposite phase) under the phase delay control code of the slave generator 7, 15 (a), as well as with the phase shift between them on a unit of discreteness $\left(0.7^{\circ}\right)$ near the phase angle $45^{\circ}$ with control code 3, 14 (b).

The creation of a precise regulated measure of phase shift for the low-frequency range, that is an urgent task of measurements in the power industry, becomes possible on the base of the developed two-phase digital generator with a phase delay scheme. The shown results of the experiments confirm that the error of synchrony in the formation of test and reference signals is not more than a few nanoseconds. This corresponds to an error of phase $0.1^{\circ}$ at a frequency of $62.5 \mathrm{kHz}$. At an operating frequency of $1 \mathrm{kHz}$, the phase error will be approximately $0.0016^{\circ}$, and at a frequency 


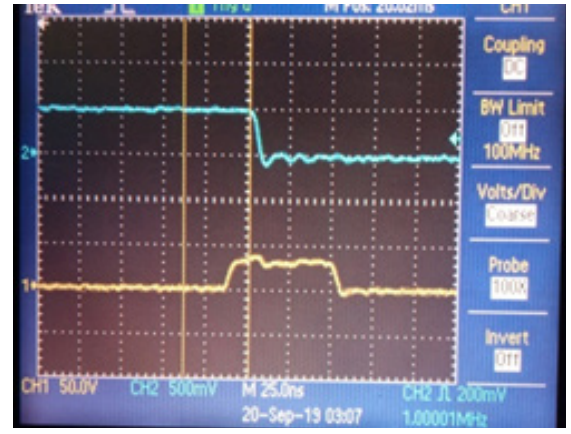

a

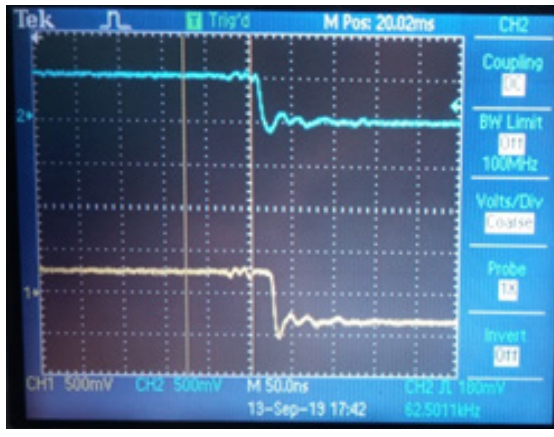

b

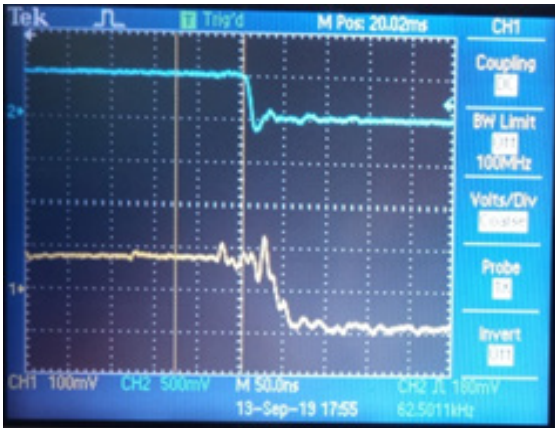

c

Figure 10. The delay (15 - 20 nsec.) of the pulse fronts for formation of quasi-sinusoidal voltage at the outputs of the DAC keys (bottom) relatively to the pulse front at the key inputs

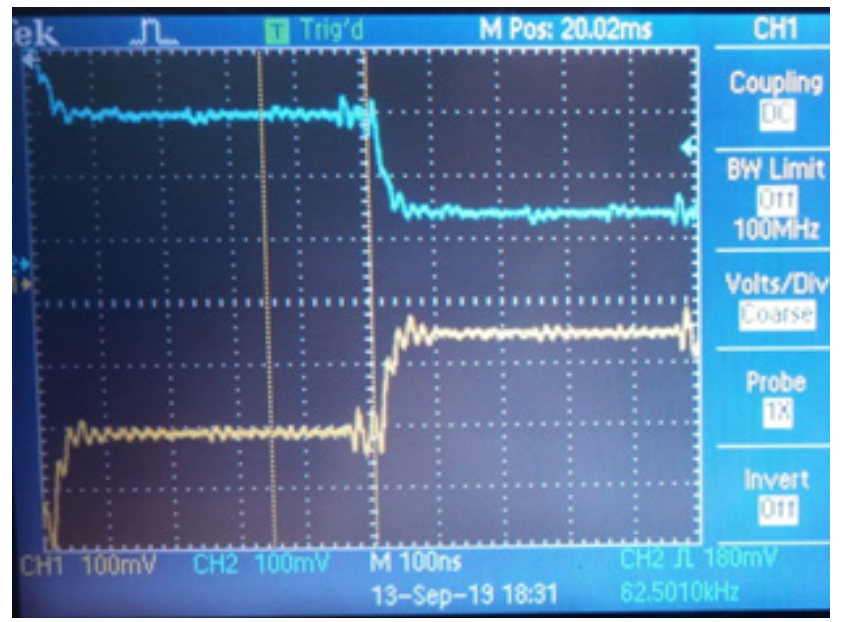

$\mathbf{a}$

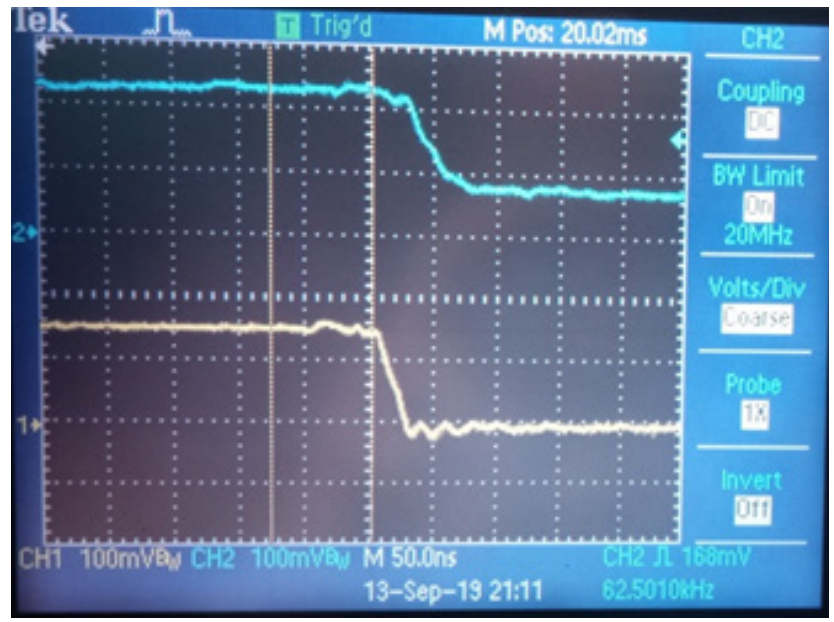

b

Figure 11. The stairs of quasi-sinusoidal signals of the master (above) and subordinate generator (in opposite phases) under delay code 7, 15 (a) and the phase shift between them by one unit of discreteness $\left(0.7^{\circ}\right)$ near the phase angle $45^{\circ}$ at code 3,14 (b)

of $50 \mathrm{~Hz}$ - no more than $0.0001^{\circ}$. The developed schemes and samples of digital generators provide limited discreteness of sinusoid approximation and phase shift regulation, which may not meet the requirements for the ethalons. Therefore, it is advisable to increase the number of triggers of the ring counter for increasing the number of stairs of the quasi-sinusoid and reducing the number of harmonics of the synthesized signal and their levels. The discreteness of phase delay regulation can be increased by doubling the bits in the delay counters FD1 - FD3 in the diagram on Fig. 3 [1]. At a clock frequency of $32 \mathrm{MHz}$, the phase control discreteness at a frequency of $1 \mathrm{kHz}$ may be less than $0.01^{\circ}$, and at a frequency of $50(60) \mathrm{Hz}$ - about $0.0007^{\circ}$. The metrological characteristics of the developed hardware and software, which are given, allow to use its also for creation of precision quadrature bridges of alternating current with phase control of balancing process.

\section{Conclusions}

Optimized structure and circuit solutions of digital generator units provide undistorted forming of signals up to the maximum operating frequencies of the applied element base (in this case up to $50 \mathrm{MHz}$ ).

The basic modules of measuring channels with new digital generators are implemented with us- 
ing of an improved method of direct conversion of impedance parameters with compensation of phase shift of the signal in the object of measurement and with balancing of the measuring circuit by module and phase. Their important metrological characteristics have been studied, the possibility of obtaining errors in modulus and tangent of the phase angle of the object of measurement not worse than $0.1 \%$ of infra-low frequencies up to $1 \mathrm{MHz}$ has been shown. At a frequency of 1 $\mathrm{kHz}$, the error in the quadrature parameter did not exceed $0.001 \%$. Taking into account the data on the sensitivity and linearity of the MXP- 6 module signal conversion channel given in [3], the total base error of the RLC meter based on the developed solutions can be expected at the level of $0.01 \%$ and below.

The researches of the characteristics of the two-phase digital generators have shown the ability to provide time differences in the formation of coherent test and reference signals of not more than a few nanoseconds. The high accuracy of highly discrete phase delay control between the signals of the master and slave generators has been experimentally confirmed.

The materials of developments and experimental researches given in this article and in article [1] confirm technical and economic efficiency of the new approaches to construction of generators of test signals and measuring channels of the impedancemetric equipment offered in previous works. The prospectiv of the developed ways of realization of these approaches have been proved for creation of the simple, technological and inexpensive, broadband and precision impedancemeasuring microsystems, in particular sensory, which on important characteristics are competitive to the existing measurement means.

\section{References}

[1]. Melnyk V. G., Borschov P. I., Beliaev V. K., Vasylenko O. D., Lameko O. L., Slitskiy $\mathrm{O}$. V. Improvement generating of the test signals for determination of the impedance parameters in wide frequency range / Sensor Electronics and Microsystem Technologies. - 2020. - T. 17, №2. - P. 60 -72. DOI: https://doi.org/10.18524/18157459.2020.2.205825.
[2]. Melnik V. G., Borshev P. I., Vasilenko A. D., Slickij A. V. Optimizaciya struktury i algoritma raboty vysokochuvstvitelnoj multisensornoj sistemy s impedansnymi preobrazovatelyami // Sensor Electronics and Microsystem Technologies. - 2018. - T. 15, № 4. - C. 100 - 109. DOI http://dx.doi.org/10.18524/18157459.2018.4.150520 . Access : http://semst.onu. edu.ua/article/view/150520/152029 .

[3]. Mizhnarodna naukovo-tehnichna konferenciya "Problemi suchasnoyi elektrotehniki - 2020", Kyiv, 08 - 12 chervnya 2020 r. Tezi ta dopovid. Dostup: https://drive.google.com/drive/ folders/14ZPzpyu_yfWva_o_bV6zE7ytVu0j56rU (in Ukrainian).

[4]. Labuzov A. E., Lameko A. L., Surdu M. N. Precizionnye izmeriteli impedansa (rlc-metry): sostoyanie rynka i tendencii razvitiya. Dostup: http://www.promix.com.ua/public/RLC.pdf (in Russian).

[5]. Surdu M. N., Lameko A. L., Karpov I. V. (Ukraine), Kinard J., Koffman A. (USA). Theoreti-cal basis of variational quadrature bridge design of alternative current. Moskow, Measurement Techniques, No 10, 2006 y. P. 58-64.

[6]. Surdu M. N., Surdu D. M., Koffman A. Teoreticheskie osnovy postroeniya mostov peremennogo toka s fazovym uravnoveshivaniem. Metrologiya-2012, Harkiv. - C. 194-198. (in Russian).

[7]. Palmsens BV Netherlands. https://www. palmsens.com/product/palmsens4/

[8]. SinePhase Impedance Analyzer 2097k | LCR Meter. https://sinephase.com/impedanceanalyzer-model-2097k-lcr-meter/ .

[9]. Wayne Kerr 65120B Impedance Analyzer. https://www.ebay.co.uk/itm/Wayne-Kerr-65120BImpedance-Analyzer-120-MHz-1J65120BD1-AL T-Keysight-E4991B/202792333922?hash=item2f 375d7262:g:TPMAAOSwsBtaLvr2 .

Стаття надійшла до редакції 04.08.2020 р. 
UDC 621.317

DOI https://doi.org/10.18524/1815-7459.2020.3.212951

\title{
IMPLEMENTATION AND EXPERIMENTAL RESEARCH OF THE TEST AND REFERENCE SIGNALS DIGITAL GENERATORS FOR IMPEDANCE MEASUREMENT IN WIDE FREQUENCY BAND
}

\author{
V. G. Melnyk', P. I. Borschov ${ }^{I}$, V. K. Beliaev², O. D. Vasylenkol, O. L. Lameko ${ }^{\text {, O. O. Slitskiy }}{ }^{1}$ \\ ${ }^{1}$ Institute of electrodynamic National Academy of Sciences of Ukraine, 56 Pr. Peremohy, 03057, \\ Kyiv-57. E-mail: melnik@ied.org.ua \\ ${ }^{2}$ National University of Life and Environmental Sciences of Ukraine, Heroyiv Oborony st., 15, \\ Kyiv, 03041, Ukraine.
}

\begin{abstract}
Summary
The structure and design of a new unified basic measuring module, which is intended for constructing broadband means for determining the impedance parameters are described. This module was used by us to study the important metrological characteristics of digital test and reference signal generators, as well as the entire measuring channel, which used in such devices. The features of the created instrument are the possibility of highly-discrete and precise regulation of the amplitude of the test signal, regardless of frequency in the range up to $1 \mathrm{MHz}$ by paired integrated digital-to-analog converters operating on direct current, and the possibility of obtaining additional coherent reference signals that are phase-controlled relative to the test signal with an accuracy of no worse than a few nanoseconds. The results of experimental studies of the regulation characteristics and a detailed study of possible sources of errors in the formation of quasi-sinusoidal test and reference signals in the ranges of their possible states are presented. The sources and the magnitudes of the modular and phase errors of the new measuring channels with direct conversion of the impedance parameters and with compensation of the phase shift of the signal in the measurement object, as well as channels with balancing the bridge circuit modulo and phase, which are based on the developed digital generators, have been determined. Ways to reduce the errors are indicated. It have been showne the possibility of obtaining errors modulo and tangent of the phase angle of the measurement object is not worse than $0.1 \%$ of infralow frequencies up to $1 \mathrm{MHz}$ and the possibility of creating a precision ethalons of the tangent of the phase angle for the industrial frequencies. At frequency of $1 \mathrm{kHz}$, the error of the instrument under study, on the parameter which is quadrature relatively the main, did not exceed $0.001 \%$.

Keywords: impedance, measurement, phase error, test signal, reference signal.
\end{abstract}


UDC 621.317

DOI https://doi.org/10.18524/1815-7459.2020.3.212951

\title{
РЕАЛІЗАЦІЯ ТА ЕКСПЕРИМЕНТАЛЬНІ ДОСЛІДЖЕННЯ ШИРОКОСМУГОВИХ ЦИФРОВИХ ГЕНЕРАТОРІВ ТЕСТОВИХ І ОПОРНИХ СИГНАЛІВ ДЛЯ ВИМІРЮВАННЯ ІМПЕДАНСУ
}

\author{
В. Г. Мельник', П. І. Борщзов ${ }^{1}$ В. К. Бєляєв ${ }^{2}$, О. Д. Василенко ${ }^{1}$, О. Л. Ламеко, О. В. Сліиьький \\ ${ }^{1}$ Інститут електродинаміки НАН України пр. Перемоги 56, м. Київ-57, 03057, Україна. E-mail: \\ melnik@ied.org.ua \\ ${ }^{2}$ Національний університет біоресурсів та природокористування України, \\ Вул. Героїв Оборони, 15, Київ, 03041, Україна
}

\section{Реферат}

Описано структуру та конструкцію нового уніфікованого базового вимірювального модуля, призначеного для побудови широкосмугових засобів визначення параметрів імпедансу, який було використано для досліджень важливих метрологічних характеристик цифрових генераторів тестових і опорних сигналів та всього вимірювального каналу, що застосовуються в таких приладах. Особливістями створеного пристрою є можливість високо-дискретного і точного регулювання амплітуди тестового сигналу незалежно від його частоти в діапазоні до 1 МГц, за допомогою спарених інтегральних цифро-анаолгових перетворювачів, що працюють на постійному струмі, а також можливість отримання додаткових когерентних референсних сигналів, що регулюються за фазою відносно тестового сигналу з точністью не гірше кількох наносекунд. Представлені результати експериментальних досліджень регулювальних характеристик та детального вивчення можливих джерел похибок формування квазісинусоїдальних тестових та референсних сигналів в діапазонах їх можливих станів. Визначено джерела i оцінено величини модульних і фазових похибок нових вимірювальних каналів на основі розроблених цифрових генераторів з прямим перетворенням параметрів імпедансу та компенсацією фазового зсуву сигналу в об’єкті вимірювання, а також каналів зі зрівноваженням мостового вимірювального кола за модулем і фазою. Вказані шляхи їх зменшення. Показана можливість отримання похибок за модулем та тангенсом фазового кута об'єкта вимірювання не гірше 0,1\% від інфранизьких частот до 1 МГц і можливість створення прецизійної міри тангенса фазового кута на промисловій частоті. На частоті 1 кГц похибка досліджуваного приладу по квадратурному параметру відносно основного не перевищувала $0,001 \%$.

Ключові слова: імпеданс, вимірювання, фазова похибка, тестовий сигнал, опорний сигнал. 